\title{
Heterologous expression, immunochemical and computational analysis of recombinant human interferon alpha $2 \mathrm{~b}$
}

\author{
Iram Gull, Zahoor Qadir Samra, Muhammad Shahbaz Aslam and Muhammad Amin Athar
}

\begin{abstract}
Interferon alpha 2b (IFNa-2b) is an important cytokine and used for antiviral and anticancer treatment. The low cost production of IFNa-2b with high biological activity is necessary to provide the interferon therapy to the hepatitis patients in Pakistan. In the present study, human interferon alpha $2 \mathrm{~b}$ (hIFNa-2b) gene from a healthy person was cloned and overexpressed in E. coli BL21(DE3). The molecular weight of the expressed hIFNa-2b is $19 \mathrm{kDa}$. The over expressed recombinant hIFNa-2b was checked by ELISA using antibodies raised against commercially available hIFNa-2b. The biocomputational analysis of recombinant hIFNa-2b gene showed the $99.9 \%$ nucleotide sequence and $100 \%$ deduced amino acid sequence homology with reported sequences of IFNa-2b. The predicted 3Dstructure showed mainly five a-helices, one 310 helix and two disulfide bonds at Cys1-Cys98 and Cys129-Cys138. The amino acid sequence alignment indicated that the disulfide linkage position is conserved in all IFNa family members. On the basis of sequence homology among interferon alpha family, new potent variants of hIFNa-2b with enhance efficacy can be produced. Indigenous production of IFNa-2b from gene of local population will reduce the cost and increase tolerability of interferon therapy.
\end{abstract}

Keywords: hIFNa-2b, Cloning, Overexpression, Computational analysis

\section{Introduction}

Interferons (IFNs) are multigene family of inducible cytokines which are produced in response to stimulation by certain viruses, bacteria, antigens and mitogens. Interferons are commonly classified into two types namely Type I and Type II IFNs (Samuel 2001). Type I IFNs are also known as viral IFNs, which include IFN- $\alpha$, IFN- $\beta$, IFN- $\omega$, IFN- $\varepsilon$, IFN- $v$ and IFN-k. These are considered as primary line of defense of the host immune system against infectious agents and tumour progression (Salunkhe et al. 2010). Type II IFN, also known as immune IFN, which includes IFN- $\gamma$ and induced by mitogenic or antigenic stimuli (Pestka 2007).

The type I IFNs gene cluster is located on the short arm of Homo sapiens chromosome 9 (9p21) (Diaz et al. 1994). They consist of 26 genes including 13 IFN- $\alpha$ genes, 1 IFN$\beta$ gene, 1 IFN- $\omega$ gene and 11 IFN pseudogenes (Roberts et al. 1998). All these genes lack introns. Among 13 IFN- $\alpha$

\footnotetext{
* Correspondence: iramgull86@yahoo.com

Institute of Biochemistry and Biotechnology, Quaid-i-Azam Campus, University of the Punjab, Lahore 54590, Pakistan
}

genes, a total of 28 different sequence variants have been described. These variants differ from each other in one to four amino acid positions, but share the same receptor system and exert similar biological activities. The molecular weight of individual interferon protein varies from 19 to $20 \mathrm{kDa}$ which consists of 165-166 amino acids (Allen and Diaz 1996). The three principal subtypes of IFN $\alpha-2$ are designated $\alpha-2 a, \alpha-2 b$, and $\alpha-2 c$. IFN $\alpha-2 b$ is being the predominant allele while IFN $\alpha-2 a$ is less predominant and IFN $\alpha-2 c$ only a minor allelic variant (Lee et al. 1995).

IFN $\alpha-2 b$ is a polypeptide of 165 amino acids containing four cysteine residues involved in the formation of two disulfide bridges (Nyman et al. 1998). The amino acid sequence of human interferon alpha $2 b$ (hIFN $\alpha-2 b)$ is highly similar to those of interferon alpha 2a (hIFN $-2 a$ ) with a difference of only one amino acid at position 23 (arginine in case of hIFN $\alpha-2 b$ and lysine in case of hIFN $\alpha-2 a$ (Retnoningrum et al. 2010).

IFN $\alpha-2 b$ therapy in combination with ribavirin is used for the treatment of chronic hepatitis $\mathrm{C}$ virus infection (de Ledinghen et al. 2002). However, sustained virological 
response in $60 \%$ cases and poor tolerability has been observed as limitations of this treatment (Escuret et al. 2006). The observed limitations may be due to the ethnic diversity which makes it important to search new potent variant of IFN $\alpha$ with improved biological efficacy.

Several host systems have been used for over expression of IFN $\alpha-2 b$ including Escherichia coli (Maeyer et al. 1982), Saccharomyces cerevisiae (Hitzeman et al. 1981), Streptomyces lividans (Vallin et al. 2005), Bacillus subtilis (Breitling et al. 1989), Pichia pastoris (Shi et al. 2007), Lactococcus lactis (Zhang et al. 2010), Yarrowia lipolytica (Gasmi et al. 2011), Plant nuclear genome (Ohya et al. 2001), Chloroplast (Arlen et al. 2007) and mammalian cells (Rossmann et al. 1996). All host systems have some advantages as well as some limitations. However, the maximum yield ( $3 \mathrm{~g} / \mathrm{L}$ ) of rhIFN $\alpha-2 b$ (recombinant human interferon alpha $2 \mathrm{~b}$ ) is reported from E. coli up till now (Srivastava et al. 2005).

At present, Pakistan imports rhIFN $\alpha-2 b$ from different countries that cost high for the treatment of $\mathrm{HCV}$ patients in Pakistan. Keeping in view the cost effective treatment of HCV and poor tolerability, this study was conducted for indigenous production of rhIFN $\alpha-2 b$. The gene encoding hIFN $\alpha-2 b$ from local healthy person was cloned, overexpressed and characterized. The recombinant hIFN $\alpha-2 b$ was further subjected to the computational analysis to compare our recombinant hIFN $\alpha-2 b$ with reported hIFN $\alpha-2 b$ as well as with other members of interferon alpha family. The further experiments are underway to find the binding of $\operatorname{rhIFN} \alpha-2 b$ with its receptor.

\section{Materials and methods}

\section{Cells, vectors and reagents}

E. coli strain DH5 $\alpha$, BL21-codon plus and expression vector $\mathrm{pET} 28 \mathrm{a}(+)$ were obtained from repository of Institute of Biochemistry and Biotechnology, University of the Punjab, Lahore, Pakistan. Restriction enzymes NdeI and BamHI, Taq DNA polymerase, T4 DNA ligase, RevertAid first strand cDNA synthesis kit, TA cloning kit were purchased from Fermentas Inc. Qiaquick gel extraction kit was purchased from Qiagen (USA), isopropyl- $\beta-\mathrm{d}-1$ thiogalactopyranoside (IPTG), 5-bromo-4-chloro-3-indolyl- $\beta$ d-galactopyranoside (X-gal) and all other chemicals required for routine extraction and analysis of biomolecules were purchased from Sigma Aldrich (USA). Primers were synthesized by Gene link (USA).

\section{RT-PCR}

Total RNA was extracted from human leukocytes isolated from the peripheral blood of healthy person by Trizol reagent (Invitrogen, USA). RT-PCR was done using RevertAid first strand cDNA synthesis using oligo(dT)18 as reverse primer. The primers 5'
GGACATATGGCCTTGACCTTTGCTTTACT 3' (forward primer), having NdeI site (underlined) and 5 GGCGGATCCTCATTCCTTACTTCTTAAAC 3' (reverse primer), having BamHI site (underlined) were designed on the basis of reported gene sequence (gi: 209413719). PCR reaction was performed in iCycler (Biorad) using $2 \mu \mathrm{l} \mathrm{cDNA}$ solution as template in $50 \mu \mathrm{l}$ reaction volume containing 2.5 units of Taq DNA polymerase, $1 \times$ PCR buffer, $200 \mu \mathrm{M}$ each dNTPs, $2 \mathrm{mM}$ $\mathrm{MgCl}_{2}, 0.5 \mu \mathrm{M}$ of each forward and reverse primer. Thermal cycler was programmed with the following parameters: initial denaturation for 1 minute at $94^{\circ} \mathrm{C}$ followed by 35 cycles of denaturation for 30 seconds at $94^{\circ} \mathrm{C}$, annealing for 30 seconds at $63^{\circ} \mathrm{C}$ and elongation for 30 seconds at $72^{\circ} \mathrm{C}$ with a final elongation step of 20 minutes at $72^{\circ} \mathrm{C}$. The amplicon was checked on $1 \%$ agarose gel and purified by QIAquick gel extraction kit.

\section{Characterization of cloned hIFNa-2b}

The amplified hIFN $\alpha-2 b$ gene (IAS) was ligated in pTZ57R/T vector. The recombinant vector was designated as pTA-IFN vector and transformed into chemically treated competent cells of $E$. coli strain DH5 . Recombinant colonies were selected by blue/white screening (Sambrook and Russell 2001). The E. coli clones having recombinant plasmid (pTA-IFN) were confirmed by colony PCR. The positive clones were further confirmed by release of insert (IAS) following digestion with NdeI/BamHI restriction enzymes. The insert IAS was processed further for DNA sequence analysis. For subcloning, the IFN vector was digested with NdeI and BamHI restriction enzymes and the released $567 \mathrm{bp}$ fragment was purified. The purified fragment was ligated with the pET28a (+) expression vector. The resulting recombinant expression vector (pET-28a-IAS) was used to transform BL21-codon plus competent cells as described in Sambrook and Russell (2001). To select the transformants containing pET-28a-IAS, the cells were grown in plates containing $1 \%$ Trypton, $0.5 \%$ Yeast extract, $1 \%$ Sodium chloride and kanamycin $(50 \mu \mathrm{g} / \mathrm{ml})$, $\mathrm{pH} 7.4$ at $37^{\circ} \mathrm{C}$. The positive clones were further confirmed by colony PCR and digestion with NdeI and $B a m H I$ restriction enzymes.

\section{Optimization of temperature and induction with IPTG for expression of hIFNa-2b}

A single transformed colony was used to inoculate $5 \mathrm{ml}$ LB medium containing kanamycin $(50 \mu \mathrm{g} / \mathrm{ml})$ and incubated in shaker water bath at $200 \mathrm{rpm}$ at $37^{\circ} \mathrm{C}$. When

$\mathrm{OD}_{600}$ of the bacterial culture reached $0.6,1 \mathrm{ml}$ sample from culture was removed as control. To the remaining culture, isopropyl $\beta$-d-thiogalactoside $(0.2$, $0.4,0.6,0.8$ and $1.0 \mathrm{mM}$ ) was added independently in each culture. One $\mathrm{ml}$ of each induced culture was taken 
at 2-h intervals up to $14 \mathrm{~h}$ at each temperature $(16,20$, $25,30,37$ and $\left.40^{\circ} \mathrm{C}\right)$. The induced cells were mixed with $2 \times$ SDS/PAGE sample buffer, boiled for 2 minutes and centrifuged at $5000 \mathrm{rpm}$ for 5 minutes at room temperature. The cell free supernatant was loaded in $10 \%$ SDS-PAGE to check the expression of recombinant hIFN $\alpha$-2b (Laemmli 1970).

\section{Production and partial purification of antibodies}

The 7-8 week old four male $\mathrm{Balb} / \mathrm{C}$ mice, weighing nearly $200 \mathrm{gm}$ were immunized interperitonially with denatured commercially available hIFN $\alpha-2 b$ (Uniferon $12 \mu \mathrm{g} /$ injection). The interferon injection was mixed with Freunds complete adjuvant in 1:1 ratio. The immunization dose was adjusted 30-40 $\mu \mathrm{g}$ of hIFN $\alpha-2 \mathrm{~b}$ per injection at 15 days intervals with a total of four injections. The antibody titre was checked by enzyme linked immunosorbent assay by drawing $100 \mu \mathrm{l}$ of blood from mouse orbital vein. The mice were anesthetized and whole blood was isolated. Serum was separated and stored at $-20^{\circ} \mathrm{C}$. The antibodies were partially purified by mixing with $\left(\mathrm{NH}_{4}\right)_{2} \mathrm{SO}_{4}$ at $50 \%$ saturation. The proteins were separated by centrifuging at $5000 \mathrm{rpm}$ for 10 minutes at $4^{\circ} \mathrm{C}$. The separated proteins fraction pellet was dissolved in $0.05 \mathrm{M}$ Tris- $\mathrm{Cl}, \mathrm{pH} 7.4$ and dialyzed against the same buffer. The dialyzed antibodies were aliquoted and stored at $-20^{\circ} \mathrm{C}$. Preimmune serum was used as control.

\section{Enzyme linked immunosorbent assay}

$100 \mu \mathrm{l}(2 \mu \mathrm{g})$ of commercially available hIFN $\alpha-2 \mathrm{~b}$ (Uniferon, Interlong and Anferon) were mixed with $100 \mu \mathrm{l}$ of $0.05 \mathrm{M}$ carbonate buffer, $\mathrm{pH} 9.0$ and absorbed on flat bottom microtitre plates for 2 hours at $37^{\circ} \mathrm{C}$. The nonspecific binding sites in microtitre plate were blocked with blocking buffer (5\% skim milk in Phosphate buffer saline-Tween 20, (PBST) by incubating at $37^{\circ} \mathrm{C}$. After washing in PBST, the partially purified mouse anti-rhIFN $\alpha-2 b$ antibody (1:100 dilution) was added and kept for one hour at $37^{\circ} \mathrm{C}$ with continuous shaking. Again after washing, rabbit anti-mouse IgG antibody alkaline phosphatase conjugated (1:2000 dilution) was added and incubated for 30 minutes at $37^{\circ} \mathrm{C}$. After washing in PBST, $0.2 \mu \mathrm{l}$ of para-nitrophenyl phosphate (PNPP) was added as substrate for color development. Preimmune serum was used as control. The overexpressed rhIFN $\alpha-2 b$ produced in this study was also checked by ELISA as described above. Untransformed BL21-codon plus cells were used as control.

\section{Computational analysis}

The BLAST program was used to compare sequence of cloned hIFN $\alpha-2 b$ with the reported IFN $\alpha-2 b$ gene. The deduced amino acid sequence was determined by using the TRANSLATE tool available on ExPASY. The homology of the nucleotide and deduced amino acid sequence of rhIFN $\alpha-2 b$ was evaluated and compared with reported subtypes of IFN $\alpha$ family members by using the CLUASTALW program. The tertiary structure of recombinant hIFN $\alpha$-2b was predicted using PHYRE server on ExPASY. All the programmes used for computational analysis are freely available online. After logging in the programs, data was submitted for analysis and results were obtained.

\section{Accession number}

The full length cDNA sequence of recombinant hIFN $\alpha$ $2 \mathrm{~b}$ gene was submitted to the Gene Bank database. The accession number of the gene is JN591570.

\section{Results}

\section{Cloning and characterization of hIFNa-2b gene}

The gene fragment of $567 \mathrm{bp}$ encoding human IFNa-2b was amplified by RT-PCR from leukocytes isolated from peripheral blood of healthy person. The purified PCR product (567 bp) was cloned in $\mathrm{pTZ} 57 \mathrm{R} / \mathrm{T}$ vector to generate pTA-IFN recombinant plasmid. The cloning of IFN $\alpha-2 b$ gene in $\mathrm{pTZ} 57 \mathrm{R} / \mathrm{T}$ vector was confirmed by amplification of 567 bp fragment by colony PCR. The release of same size fragment after digestion of recombinant plasmid pTA-IFN with restriction enzymes NdeI and $\mathrm{BamHI}$ further confirmed the cloning of IFN $\alpha-2 \mathrm{~b}$ gene (Figure 1). The IFN $\alpha-2 b$ gene fragment was subcloned into the pET28a (+) expression vector. The resultant recombinant plasmid was designated as pET28a-IAS. The E. coli BL21-codon plus cells were transformed with pET28a-IAS recombinant expression vector for the expression of IFN $\alpha-2 b$ gene. The restriction digestion of the recombinant vector pET28a-IAS with restriction enzymes NdeI/ BamHI and colony PCR confirmed the presence and orientation of the $567 \mathrm{bp}$ IFN $\alpha-2 \mathrm{~b}$ gene (Figure 2).

\section{Expression and characterization of IFNa-2b gene}

E. coli strain BL21 Codon Plus cells containing recombinant pET28a-IAS plasmid were grown in LB medium containing kanamycin $(50 \mu \mathrm{g} / \mathrm{ml})$ and optimized for maximum expression as described in materials and methods. The expression was induced by IPTG and checked in cell lysates of induced recombinant strain by sodium dodecyl sulfate-polyacrylamide gel electrophoresis and finally compared with the wild type (uninduced cells). The recombinant human IFN- $\alpha 2 b$ protein having molecular weight of approximately $19 \mathrm{kDa}$ was overexpressed in E. coli strain BL21 Codon Plus after induction with IPTG. The maximum expression of recombinant protein was observed by induction with $1 \mathrm{mM}$ IPTG for 6 hours at $37^{\circ} \mathrm{C}$ (Figure 3). 


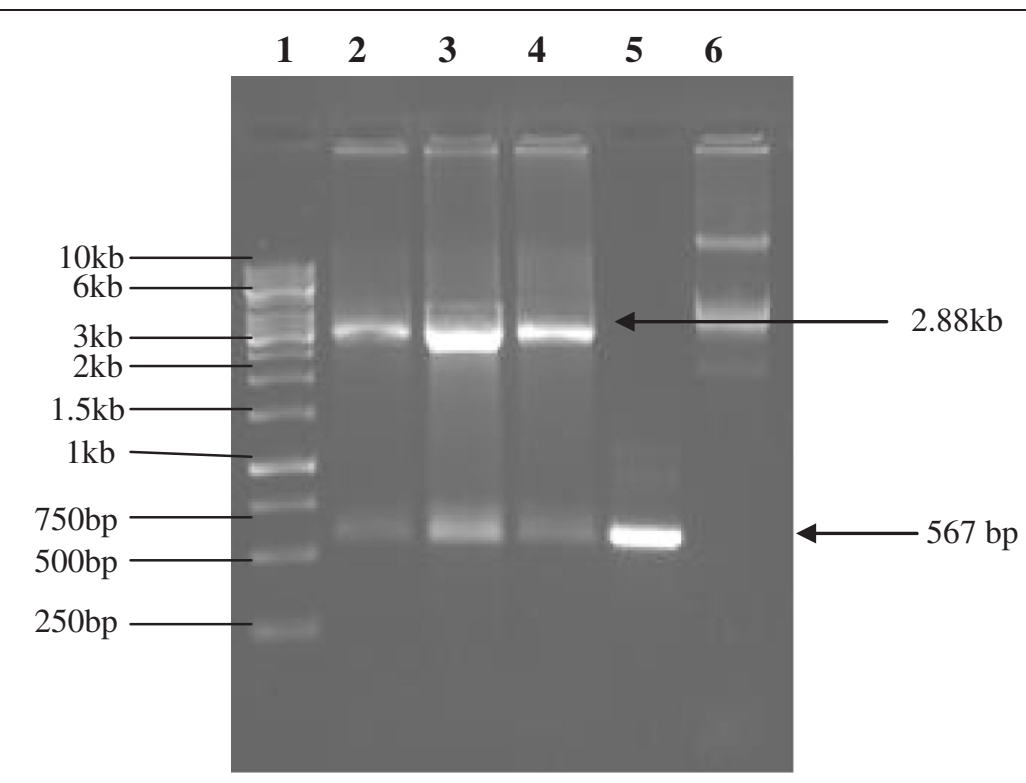

Figure 1 Agarose gel (1\%) electrophoretic analysis of pTA-IFN vector restriction digestion. Lane 1 DNA size marker, Lane 2-4 Restriction digestion of pTA-IFN vector from three different clones with Ndel and BamHI restriction enzymes. Two bands corresponding to $2.886 \mathrm{~kb}$ pTZ57R/T vector and 567 bp insert are indicated by arrows. Lane 5, hIFNa-2b gene, Lane 6 Undigested pTA-IFN vector.

\section{Antibodies production and characterization}

When antibodies raised against commercially available hIFN $2 \mathrm{~b}$ were checked against overexpressed rhIFN $\alpha 2 b$ and other commercially available hIFN $\alpha 2 b$ by ELISA, it was noted that rhIFN $2 \mathrm{~b}$ and commercially available hIFN $\alpha 2 b$ were reacting with antibodies. The bacterial cells of BL21-codon plus $\left(1 \times 10^{6}\right)$ carrying recombinant pET28a-IAS plasmid, harvested at 2 hour interval after

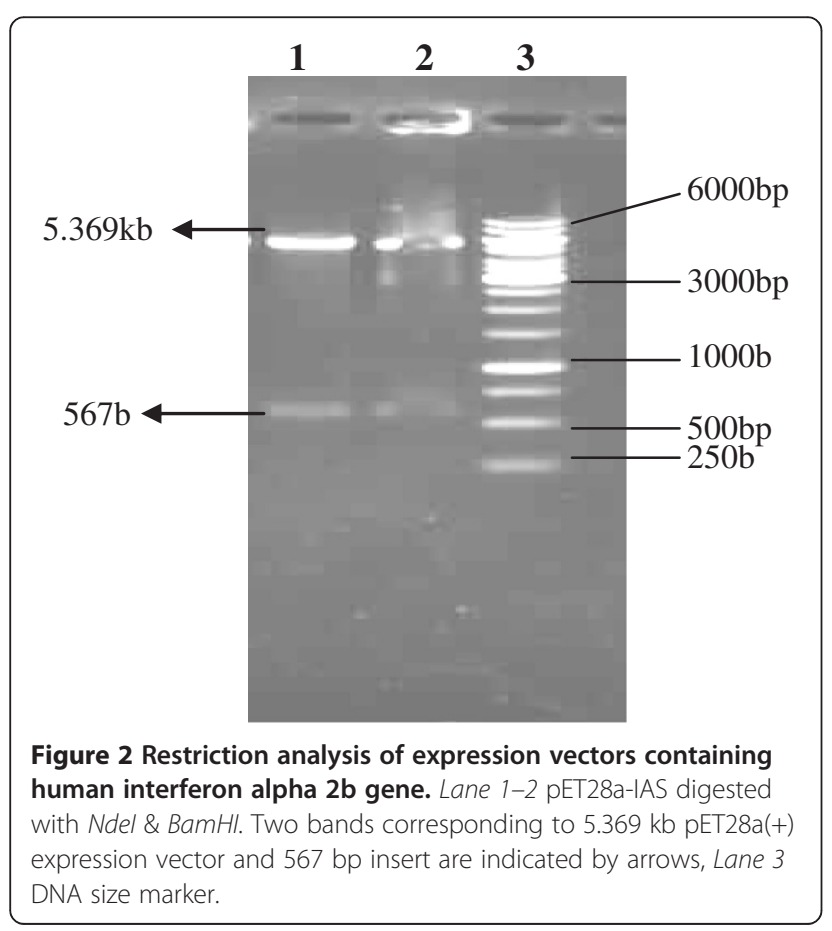

induction with IPTG, were lysed and supernatant was used to quantify the total protein by Bradford reagent assay (Bradford 1976). Serial dilutions of protein contents were made and coated on microtitre plate for ELISA. The anti-hIFN- $\alpha 2 b$ antibodies (1:100 dilution) were used in serial dilutions. The intensity of colour reaction in the plate wells further indicated the higher expression of rhIFN- $\alpha 2 b$ after 6 hours.

\section{Computational analysis}

The sequencing of pTA-IFN and pET28a-IAS vectors further confirmed the cloning of hIFN $\alpha-2 b$ gene (IAS). The analysis of DNA sequence data of recombinant hIFN- $\alpha 2 b$ (accession number JN591570) showed 99.9\%

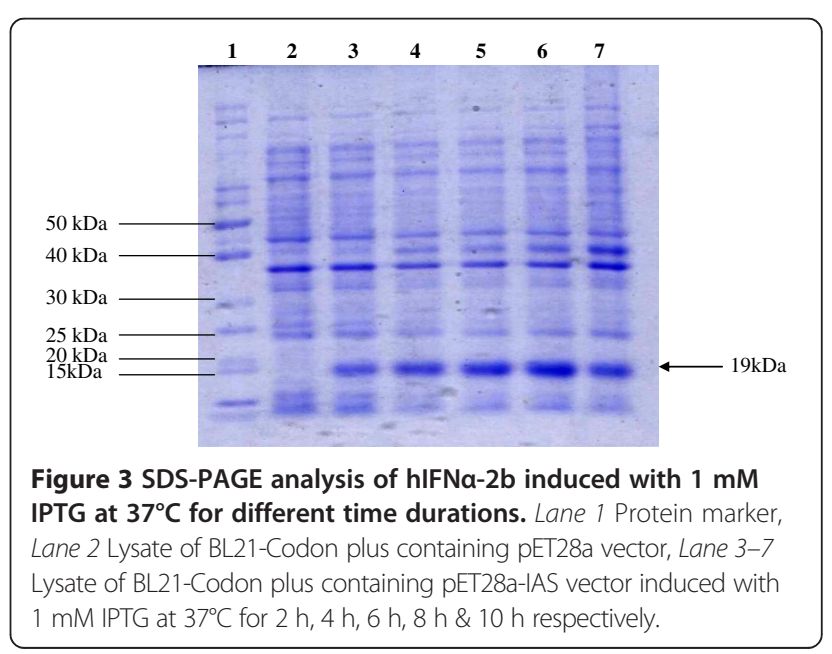


homology with the reported sequences of IFN $\alpha 2 b$ available on Genebank. One nucleotide difference was observed at nucleotide position number 273 where cytosine (C) was replaced by thymine (T) which changed the codon from AGC to AGT (Figure 4). However this mutation was sense mutation as alignment by CLUSTALW revealed that it had $100 \%$ identity at deduced amino acid level with the reported IFN- $\alpha 2 b$ sequence (Figure 5 ). Starting from Nterminal, first 23 amino acids were comprised of the signal peptide. Excluding signal peptide, the tertiary structure model of rhIFN- $\alpha 2 \mathrm{~b}$ was predicted which indicated only $\alpha$-helices in the structure. The predicted tertiary structure has seven $\alpha$-helices starting from $\mathrm{N}$-terminal named as helix A (residue 9-21), B (residue 26-32), C (residue 5268), $\mathrm{D}$ (residue 70-75), E (residue 78-100), F (residue 111-133), \& G (residue 137-155) (Figure 6). Two disulfide bonds: Cys1-Cys98 and Cys29-Cys138 were observed in the structure of IFN- $\alpha 2 \mathrm{~b}$. The 13 different subtypes of interferon alpha (IFN $\alpha 1$, IFN $\alpha 2$, IFN $\alpha 4$, IFN $\alpha 5$, IFN $\alpha 6$, IFN $\alpha 7$, IFN $\alpha 8$, IFN $\alpha 18$, IFN $\alpha 13$, IFN 14 , IFN $\alpha 16$, and IFN $\alpha 17$ \& IFN 221$)$ were compared and it was observed that different subtypes were comprised of 165-166 amino acids and share $70-75 \%$ amino acid identity. The four cystein residues Cys 1, Cys 29, Cys 98/99 \& Cys 138/139 involved in disulfide bond formation were conserved in all interferon alpha subtypes (Figure 7).

\begin{tabular}{|c|c|}
\hline $\begin{array}{l}\text { Reported } \\
\text { IAS }\end{array}$ & 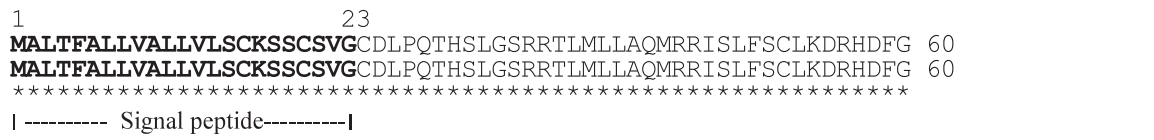 \\
\hline $\begin{array}{l}\text { Reported } \\
\text { IAS }\end{array}$ & 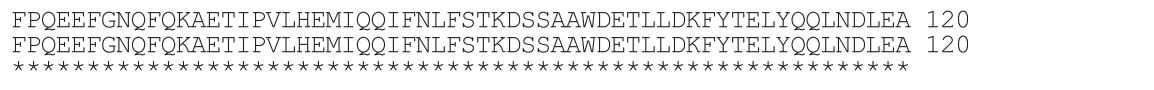 \\
\hline $\begin{array}{l}\text { Reported } \\
\text { IAS }\end{array}$ & 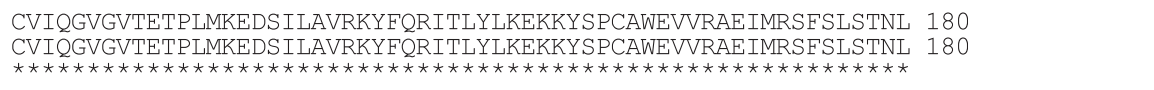 \\
\hline $\begin{array}{l}\text { Reported } \\
\text { IAS }\end{array}$ & 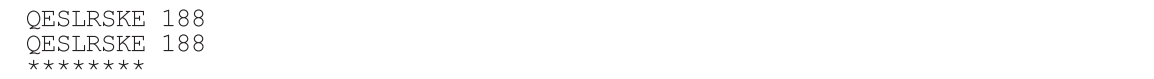 \\
\hline \multicolumn{2}{|c|}{$\begin{array}{l}\text { Figure } \mathbf{5} \text { Comparison of amino acid sequence of cloned IFNa-2 } \mathbf{b} \text { with reported amino acid sequence of IFNa-2b. Amino acid } 1-23 \text { are } \\
\text { part signal peptide. Asterik }\left(^{*}\right) \text { indicates the identical amino acids in both sequences. }\end{array}$} \\
\hline
\end{tabular}




\section{Discussion}

The recombinant hIFN $\alpha$ has several pharmaceutical applications such as for treatment of hairy cell leukemia, metastasizing renal carcinomas, Kaposi sarcomas, a number of other tumors and viral infections, including chronic hepatitis $\mathrm{C}$ infection (Behravan and Ahmadpour 2004). Hepatitis $C$ is an emerging health problem worldwide and it has been estimated that Hepatitis $C$ virus $(\mathrm{HCV})$ has infected approximately 17 million people in
Pakistan (Akbar et al. 2009). IFN- $\alpha$ is the first choice of treatment for chronic hepatitis $\mathrm{C}$ virus (HCV) infections. In Pakistan, about $75 \%$ of patients have no access to standard anti HCV therapy (Interferon + Ribavirin) and only $25 \%$ receive such treatment (Idrees and Riazuddin 2008). There is need to make possible low cost production of interferon with high biological activity.

In this report we describe the cloning and expression of cDNA encoding hIFN $\alpha-2 b$ from our local population. 


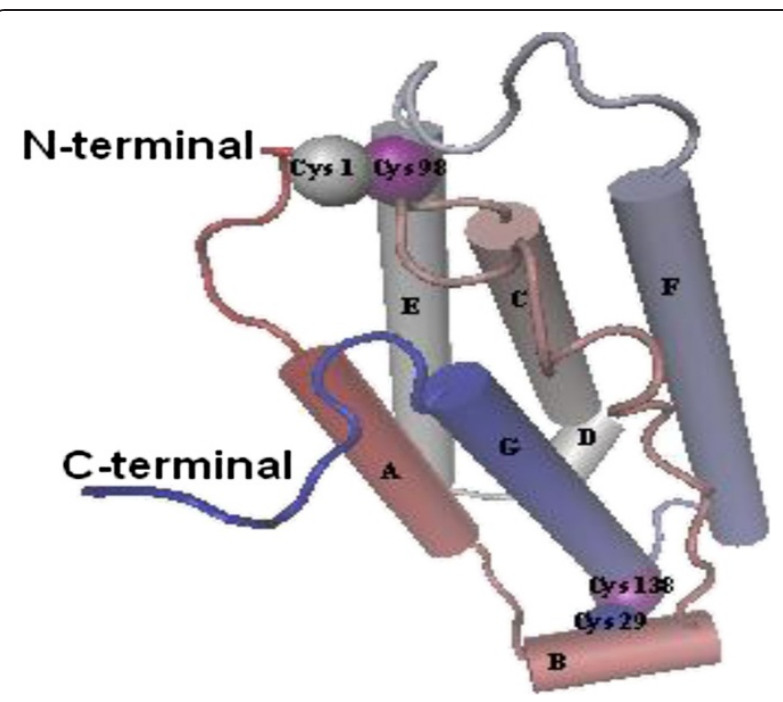

Figure 7 Predicted 3D model of recombinant human interferon alpha $2 \mathrm{~b}$ using PHYRE sever. Starting from $\mathrm{N}$-terminal, helices are indicated by alphabets $(A, B, C, D, E, F \& G)$. Helix $B$ is $3_{10}$ helix and Helix $D$ is extension of Helix $C$ separated by single amino acid. Two disulphide bonds between Cys 1-Cys 98 and Cys29-Cys138 were also shown.

By using the sequence specific primers, a fragment of 567 bp (hIFN $\alpha-2 b$ gene) was amplified and directionally cloned in pTZ57R/T to construct recombinant pTA-IFN vector. The cloning of gene was confirmed by colony PCR, restriction analysis and sequencing analysis. The maximum expression of recombinant protein was observed by induction with $1 \mathrm{mM}$ IPTG for 6 hours at $37^{\circ} \mathrm{C}$ in $E$. coli strain BL21 Codon Plus cells containing recombinant pET28a-IAS plasmid. It was confirmed by ELISA. As in ELISA, the highest intensity of color reaction was observed in the wells which were coated with cell free extract of transformed BL21 Codon Plus cells induced for 6 hours. Antibodies were developed against commercially available hIFN $\alpha-2 b$ (Uniferon) in Pakistan for detecting the rhIFN $\alpha-2 b$ produced in the present study. The reactivity of the anti-hIFN $\alpha-2 b$ antibody against hIFN $\alpha-2 b$ (Uniferon, Interlong and Anferon) of different companies was confirmed by ELISA. When the overexpressed rhIFN $\alpha-2 b$ was checked by using the same antibodies, similar results were obtained.

The nucleotide sequence analysis showed that gene of hIFN $\alpha-2 b$ consisted of 567 bp and had 99.9\% homology with the previously reported hIFN $\alpha-2 b$ gene sequence. A single nucleotide variation at nucleotide number 273 converted the codon from AGC to AGT. However, it was the sense mutation as deduced amino acid sequence was identical (100\% homology) to the previously reported amino acid sequence. The homology of considerable number of amino acids among different subtypes of interferon alpha family and conserved position of four cysteine residues involved in disulfide bond formation predict similar 3-D structure in all types (Figure 6). The structure of hIFN $\alpha-2 b$ protein mainly comprised of $\alpha$ helices and no $\beta$-sheets were observed. The $\alpha$-helices (A, $B, C, D, E, F \& G)$ are interconnected by the loops. The loop $\mathrm{AB}$ (residue 22-25) connects the helix A with helix B, loop BC (residue 33-51) connects helix B with helix C, loop $\mathrm{CD}$ (residue 69) connects helix $\mathrm{C}$ to helix $\mathrm{D}$, loop DE (residue 76-77) connects helix D with helix E, loop EF (residue 101-110) connects helix E with helix F and loop FG (residue 134-136) connects helix F with helix G (Figure 7). Different models of the interferon alpha 2 have been proposed in which five helices of interferon alpha 2b had been mentioned (Kumaran et al. 2007; Radhakrishnan et al. 1996). In the predicted 3D model of our rhIFN $\alpha-2 b$ by PHYRE, helix $B$ and helix D are presented as independent helices whereas in five helices model, they were considered as loops. According to the model of Kontsekova et al. (1999) loop AB ranges from residue 22 to 51 exhibits structural diversity. The two portions in the loop, residue 26-29 and residue 30-33, form two turns of $3_{10}$ helix $\left(3_{10} \mathrm{~A}\right.$ and $\left.3_{10} \mathrm{~B}\right)$ where $3_{10} \mathrm{~B}$ is the part of receptor binding segment (residue 30-46) and involved in interaction of human IFN $\alpha-2 b$ with its cellular receptor. The helix B of our model is actually the two turns of $3_{10}$ helix. The helix $\mathrm{D}$ is the extension of helix $\mathrm{C}$ as only single amino acid separated the two helices. All the helices of IFN $\alpha-2 b$ are straight except helix C. It actually extended from residue 52-75 with a bend of $70^{\circ}$ at Thr 69 (Kumaran et al. 2007). Hence, the structure of IFN $\alpha-2 b$ is mainly consists of five $\alpha$-helices whereas presented helix $B$ is $3_{10}$ helix not a $\alpha$-helix and helix D is extension of helix $C$.

The hIFN $\alpha-2 b$ protein has six cysteine residues in which two are present in signal peptide. After the removal of signal peptide, mature protein has four cysteine residues involved in the formation of two disulfide bonds. All alpha-interferon subtypes have two conserved disulfide bonds; Cys1-Cys98/99 and Cys29-Cys138/139. Although several interferon alpha subtypes shares high amino acid homology, conserved secondary structure but they bind by varying degree of affinity with same receptor which results in different antiviral and antiproliferative potencies of different subtypes of IFN $\alpha$. The sequence analysis of IFN $\alpha$ family members presented in this study provides a gateway for identification of functionally relevant amino acid mutations for designing IFN $\alpha-2 b$ variants with enhanced antiviral activity. At low dose such rhIFN $\alpha-2 b$ variants would have high antiviral or antiproliferative activity which will be helpful in reducing the high treatment cost of Hepatitis. Further research work is under investigation for understanding the binding affinity of rhIFN $\alpha-2 b$ for its receptor. 


\section{Competing interests}

The authors declare that they have no competing interests.

\section{Authors' contributions}

All authors equally participated in designing experiments, acquisition, analysis and interpretation of data. MAA critically revise the manuscript and approved the final version of manuscript. All authors read and approved the final manuscript.

Received: 11 April 2013 Accepted: 11 June 2013

Published: 15 June 2013

\section{References}

Akbar H, Idrees M, Manzoor S et al (2009) Hepatitis C virus infection: A review of the current and future aspects and concerns in Pakistan. J Gen Mol Virol 1:12-18

Allen G, Diaz MO (1996) Nomenclature of human interferon proteins. J Interferon Cytokine Res 16:181-184

Arlen PA, Falconer R, Cherukumilli S (2007) Field production and functional evaluation of chloroplast-derived interferon-a2b. Plant Biotechnol J 5:511-525

Behravan J, Ahmadpour H (2004) Cloning and characterization of directly amplified antiviral gene Interferon alpha-2b from human leukocytes chromosomal DNA. Arch Pharmacal Res 27:776-780

Bradford MM (1976) Rapid and sensitive method for the quantitation of microgram quantities of protein utilizing the principle of protein-dye binding. Anal Biochem 72:248-254

Breitling R, Gerlach D, Hartmann M et al (1989) Sercretary expression in Escherichia coli and Bacillus subtillis of human interferon alpha genes directed by staphylokinase signals. Mol Genet Genomics 217:384-391

de Ledinghen V, Trimoulet P, Winnock M et al (2002) Daily or three times per week interferon $a-2 b$ in combination with ribavirin or interferon alone for the treatment of patients with chronic hepatitis $C$ not responding to previous interferon alone. J Hepatol 36:819-826

Diaz MO, Pomykala HM, Bohlander SK et al (1994) Structure of the human type-I interferon gene cluster determined from a YAC clone contig. Genomics 22:540-552

Escuret V, Martin A, Durantel D et al (2006) Novel alpha interferon (IFN- a) variant with improved inhibitory activity against hepatitis C virus genotype 1 replication compared to IFN- $\mathrm{a} 2 \mathrm{~b}$ therapy in subgenomic replicon system. Antimicrob Agents Chemother 50:3984-3991

Gasmi N, Fudalej F, Kallel H et al (2011) A molecular approach to optimize hIFN $\mathrm{a} 2 \mathrm{~b}$ expression and secretion in Yarrowia lipolytica. Appl Microbiol Biotechnol 89:109-119

Hitzeman RA, Hagie FE, Levine HL et al (1981) Expression for human gene for interferon in yeast. Nature 293:717-722

Idrees M, Riazuddin S (2008) Frequency distribution of hepatitis C virus genotypes in different geographical regions of Pakistan and their possible routes of transmission. BMC Infect Dis 8:69

Kontsekova E, Liptakova H, Mucha V et al (1999) Structural and functional heterogeneity of the amino-terminal receptor-binding domain of human interferon-alpha 2. Int J Biol Macromol 24:11-14

Kumaran J, Wei L, Kotra LP et al (2007) A structural basis for interferon-a-receptor interactions. FASEB J 21:3288-3296

Laemmli UK (1970) Cleavage of structural proteins during the assembly of the head of bacteriophage T4. Nature 227:680-685

Lee N, Ni D, Brissette R et al (1995) Interferon-alpha 2 variants in the human genome. J Interferon Cytokine Res 15:341-349

Maeyer ED, Skup D, Prasad KS et al (1982) Expression of a chemically synthesized human alpha 1 interferon gene. P Natl Acad Sci USA 79:4256-4259

Nyman TA, Lo HT, Parkkinen J et al (1998) Identification of nine interferon-a subtypes produced by Sendai virus induced human peripheral blood leucocytes. J Biochem 329:295-302

Ohya K, Matsumura T, Ohashi K (2001) Expression of two subtypes of human IFNalpha in transgenic potato plants. J Interferon Cytokine Res 21:595-602

Pestka S (2007) The interferons: 50 years after their discovery, there is much more to learn. J Biol Chem 282:20047-20051

Radhakrishnan R, Waltyer LJ, Hruza A et al (1996) Zinc mediated dimer of human interferon alpha 2b revealed by X-ray crystallography. Structure 4:1453-1463

Retnoningrum DS, Ningrum RA, Kurniawan YN et al (2010) Construction of synthetic open reading frame encoding human interferon alpha $2 \mathrm{~b}$ for high expression in Escherichia coli and characterization of its gene product. J Biotechnol 145:193-198
Roberts RML, Liu Q, Guo D et al (1998) The evolution of the type I interferons. J Interferon Res 18:805-816

Rossmann C, Sharp N, Allen G et al (1996) Expression and purification of recombinant, glycosylated human interferon alpha $2 \mathrm{~b}$ in murine myeloma NSo cells. Protein Expres Purif 7:335-342

Salunkhe S, Soorapaneni S, Prasad KS et al (2010) Strategies to maximize expression of rightly processed human interferon $\mathrm{a} 2 \mathrm{~b}$ in Pichia pastoris. Protein Expres Purif 71:139-146

Sambrook J, Russell DW (2001) Molecular Cloning: A laboratory manual. Cold Spring Harbor Laboratory Press, New York

Samuel CE (2001) Antiviral actions of interferons. Clin Microbiol Rev 14:778-809

Shi L, Wang D, Chan W et al (2007) Efficient expression and purification of human interferon $\mathrm{a} 2 \mathrm{~b}$ in the methylotrophic yeast, Pichia pastoris. Protein Expres Purif 54:220-226

Srivastava P, Bhattacharaya P, Pandey G et al (2005) Overexpression and purification of recombinant human interferon alpha2b in Escherichia coli. Protein Expres Purif 41:313-322

Vallin C, Pimienta E, Ramos A et al (2005) Streptomyces as a host for the secretion of heterologous proteins for the production of biopharmaceuticals. J Bus Chem 2:107-111

Zhang Q, Zhong J, Liang X et al (2010) Improvement of human interferon alpha secretion by Lactococcus lactis. Biotechnol Lett 32:1271-1277

doi:10.1186/2193-1801-2-264

Cite this article as: Gull et al:: Heterologous expression,

immunochemical and computational analysis of recombinant human interferon alpha 2b. SpringerPlus 2013 2:264.

\section{Submit your manuscript to a SpringerOpen ${ }^{\circ}$ journal and benefit from:}

- Convenient online submission

- Rigorous peer review

- Immediate publication on acceptance

- Open access: articles freely available online

- High visibility within the field

- Retaining the copyright to your article

Submit your next manuscript at $>$ springeropen.com 